\title{
Using the street in Mexico City Centre: temporary appropriation of public space vs legislation governing street use
}

\author{
J. Antonio Lara-Hernandez, Alessandro Melis, Claire M. Coulter \\ University of Portsmouth, Portsmouth School of Architecture, United Kingdom \\ antonio.lara-hernandez@port.ac.uk | alessandro.melis@port.ac.uk | claire.coulter@port.ac.uk
}

\begin{abstract}
Historically there has been a rich discussion concerning the function of streets in cities, and their role in urban life. This paper outlines the relevance of temporary appropriation for understanding social dynamics within a given urban environment, looking in particular at activities occurring in the street. It takes as a case study Mexico City Centre and examines the laws and regulations set out by the government of Mexico City which regulate the use of the street. It contrasts this with the ways in which the inhabitants of the city appropriate public space on a daily basis. There is a contrast between the lack of clarity in the legislation surrounding potential activities occurring on the street, and a seemingly tacit consensus between citizens regarding how they appropriate such public spaces. We explore this contrast and outline ways in which public space is used in traditional and unexpected ways, how creative ways are found to use the street area within the spirit of the law, and where further research on this topic this could lead in future.
\end{abstract}

Keywords: public space, temporary appropriation, streets, city centre, Mexico City Centre

To cite this article:

Lara-Hernandez, J. A., Melis, A., Coulter, C. M. (2018). Using the street in Mexico City Centre: temporary appropriation of public space vs legislation governing street use. The Journal of Public Space, 3(3), 25-48, DOI 10.32891/jps.v3i3.II 35

This article has been double blind peer reviewed and accepted for publication in The Journal of Public Space. 


\section{Introduction}

The design of the street as a public space is highly relevant for more than simply physical or aesthetic reasons; it frames our understanding of social encounters in the public realm. The creation of environments that support social behaviour in places is one of the most important roles of urban design (Mehta, 20I3).

Human beings have the inborn need to interact with each other. Mumford (1938) claims that the city, above all else, is a theatre of social action. This suggests that there is a dialogue between people and physical spaces or environments. This dialogue is spatialised through people's activities occurring in the spaces, and has been defined differently throughout time. For instance, street ballet by Jacobs (196I) or the space of contact by Choay (200I), in where all the different social encounters happening in the street, such as children playing, people walking, or sitting at a table drinking coffee, mean that public spaces in cities are the physical environment where this interaction between citizens takes place. According to Rywert (Anderson, 1986), the expectation of daily human contact that public space offers is unique. When public spaces do not allow this contact, one of the possible risks is a rise in alienation, which contributes to social stress, unused space, and an increase in crime rates. Moreover, since cars have taken over most of the street space, the only place where the street ballet occurs is on the sidewalk (Minnery, 20I2). The street is the immediate public space where urban life is evidenced.

In this paper we explore how the use of public space is currently regulated in Mexico City Centre (MCC), and how this differs from the ways in which public space has historically been used. We note the discrepancies and loopholes in current legislation, and show how the day to day use of public space in MCC occurs alongside, and sometimes despite, legislation.

With a total population of over 21 million Mexico City forms the core of the fourth largest urban agglomeration in the world, and is both the world's largest Spanish speaking city and the largest city in the Western hemisphere (United Nations, 20 I4). It is a forerunner of the trend towards the growth of megacities in the Global South, and its residents are part a deeply unequal society, where wealth is concentrated in the hands of the few and where informal commerce and construction have become a means of survival for many. It also experiences high numbers of people coming into the city each day for work, leisure and other pursuits (Nivon Bolan \& Sanchez Bonilla, 20I4; Villanueva et al., 2012). The size and population structure of Mexico City make it an interesting choice for exploring how public space is currently being used in a global megacity, and for hinting at how the use of public space may change in other rapidly expanding Latin American urban centres. As Herzog (2004) notes, "Mexico City encapsulates what we might call the 'yin/yang' of globalization-it houses both the best and the worst of our global future." The paper is divided into three main sections. The first outlines the concept of temporary appropriation (TA), and discusses its relevance as a theoretical concept for understanding the relationship between people and places. The second section attempts to clarify the legal framework that regulates the use of streets in MCC. The third section places the concept of TA within the specific research context, in this case MCC. It explores historical and contemporary uses of public space in MCC, and the varying ways in which TA can be categorised within this research setting. The legal framework for street use stands in contrast to the way in which streets are actually being used, and forms the basis for the discussion of perceived, actual and desired use of public spaces within MCC, 
viewed through the lens of TA. Finally, we conclude by showing the tension between the popular and legislative use of the streetscape, and suggest areas where this could be further explored in future.

\section{Temporary appropriation in the urban context}

Temporary appropriation is relevant as a theoretical concept for understanding the relationship between people and public spaces. Although there is no formal definition of appropriation, other theories incorporate and approach the concept, claiming that it plays a key role in creating the bond between people and places that leads to the social construction of public spaces. In previous work we have explored in depth how TA can offer a valid alternative way of reading the urban landscape (Lara-Hernandez \& Melis, 2018), looking at the development of the idea of appropriation from its first use in this context in Korosec-Serfaty (1976) and Sansot, (1976). We show how more recent work on appropriation, such as the topophilia theory of Yory García (20I I; 2003), fits with Lefebvre (197I), who argues that without appropriation, the domination of nature does not have a purpose; there is no urban realm if public spaces are not appropriated. TA is an individual, social, and spatial need that cannot be underestimated when it comes to urban studies, and forms the vital theoretical link between people and places (LaraHernandez \& Melis, 20I8). Fonseca-Rodriguez (2015) provides a definition incorporating the temporality of the concept by defining temporary appropriation (TA) as "the act in which people use public spaces to carry out individual or collective activities other than the purpose that the space was originally designed for". This definition helps us to better conceptualise TA as an urban phenomenon.

Looking at the context of MCC, although a considerable amount of literature (Gehl, 2014; Jacobs, 1961; Whyte, 1980) discusses and analyses the physical attributes of the built environment for the purpose of creating lively and inclusive public spaces, studies on the subject in Latin America have only focused on the processes of segregation (Oehmichen, 20I0), gentrification (Martinez-Ramirez, 20I5), and exclusion (Bayón, 2008) occurring in city centres. Alternative authors, such as Carrion (20I3), Garcia Espinosa (2005), Hernandez Bonilla and Gomez Gomez (2015) and Hidalgo et al. (2008) deal with the effects caused by transforming the built environment to create public spaces in city centres in Latin America, however they fail to consider the new public spaces in terms of their ongoing use and TA by the public, let alone exploring the current legal framework that defines the uses permitted for each space in the local context.

\section{I.I Forms of temporary appropriation of public space}

Public spaces are the arenas in which many activities can occur, ranging from leisure pursuits to political protests. Nevertheless, not all activities are the spatialised expression of appropriation. According to Sansot (1976) people only appropriate places which they identify with. Torres (2009) argues that the appropriation of public space is strongly valued by people, since it is culturally constructed by everyday activities. This implies that appropriation of the space plays a key role in people's identities and their interactions with their environment.

Even though a breadth of literature describes the importance of the use of the space in which people, through their activities, appropriate public spaces (Korosec-Serfaty, 1976; Gutierrez de Velasco Romo \& Padilla Lozano, 2012; Alessandri Carlos, 2014; Fonseca 
Rodriguez, 20I5), few studies fully specify or classify such activities. Activities relating to trade and commerce commonly occur in public spaces and are associated with appropriation, however there are uncountable other activities occurring besides those linked with profit. Furthermore, while discussing public spaces as a concept we commonly tend to associate this with parks or squares, leaving the street aside. Scholars such as Jacobs (196I), Mourdon (199I), Jacobs (1993), Choay (200I), Gehl (20II), Kim (20I3) have described the street as a quintessential public space within the urban realm. The street is a versatile space because even when its meaning is shaped it can be changed, boundaries can be re-defined, new activities can take place and its time management may change too (Mehta, 2013). The space where this conflict is most evident is in public space, commonly in the streets, which is the place that serves as the locus of collective expressions for those who are deprived of institutional settings to disagree (Roy \& Alsayyad, 2004). Deleuze and Guattari (1989) suggest that the street is the space for the operation denominated overcoding by excellence in which community, state and tradition super impose their code with concrete implications towards the urban realm. The street as urban space is under constant tension between its function as infrastructure and as public space.

As indicated previously there is an infinite number of activities that public spaces could host, however we attempted limit our investigation to those activities in the street which can be classified as those where people appropriate public space. Only by identifying and classifying these forms of TA will it be possible to achieve a deeper understanding of such activities, and their relationship with the street as a public realm. The broad categories that we identified are explored in detail in the paragraphs which follow.

\section{I.I.I Economic actions and temporary appropriation}

According to Ramirez Kuri (2010), there are three types of TA related to commerce or services. First, people such as vendors or workers use the space with or without the authorisation of government authorities; second, people work in public spaces as an extension of their place of work because it is close by; lastly, people gather in the public space, with clients who travel there to find them and use their services, such as mariachi bands. Gutierrez de Velasco Romo and Padilla (20I2)agree with the identification of these three types of the occurrence of TA of public spaces in central areas. Even though informal commerce on the street is usually perceived as an undesirable activity by governments in different cities (Ramirez-Lovering, 2008; Kim, 2013), it is without any doubt an activity in which people worldwide temporarily appropriate the street.

\section{I.I.2 Leisure and temporary appropriation}

Activities related to leisure, such as arts or sport, are also evidence of TA. Cranz (1982) claimed that recreational and leisure activities occurring in public spaces, such as parks, have a strong influence on urban political processes in North American culture. Crouch (1998) explores the significance of the street as an everyday site of geographical knowledge and leisure practice, revealing the rituals and relationships, and practices and representations which are played out routinely on the street. He also states that the design of both the streets and the buildings dictate the experience of a place. Both authors imply that through leisure and recreational activities, people appropriate public spaces; it is emotionally beneficial when people participate in leisure activities in public 
spaces because they feel comfortable to do so, but it is even more important that they feel as if they own the space.

\section{I.I.3 Sacralisation and temporary appropriation}

In countries with a strong religious cultural background, another activity in which people appropriate public spaces is through sacralisation. Portal (2009a) describes the term sacralisation by referring to religious symbols (mostly Catholic) being placed in a public space. This form of appropriation is particularly characterised by the installation of crosses or altars in public spaces, where people may pray. According to Portal (2009a), there are two main causes for this kind of appropriation. First, as an act of personal or familial commemoration, for instance because a friend or relative has died on the site or close to it. Portal (2009a) notes that for violent deaths, a cross can be seen as a way of helping the soul to find peace on its onward journey. In other situations, flowers and other artefacts can be placed on the site to mark the place where a death occurred, appropriating the space for personal commemoration. The second cause to mark or define territories at the boundary of a determinate area or neighbourhood, and can be sued to reduce anti-social behaviour within a designated area ((Portal, 2009a, 2009b). Santino (1992) explores this idea further, noting that artefacts forming public displays of commemoration not only invite spectatorship, but through their invitation to bear witness, involve passers-by otherwise unconnected to the event in the act of TA, as outlined by Habermas (199I) through his ideas on shared civic interest.

\section{I.I.4 Summary}

People make use of public space for a variety of reasons, and to undertake a wide assortment of activities. We have aimed to categorise these as simply as possible under the broad headings of economy, leisure and sacralisation, but appreciate that under each of these headings a complex network of activities is taking place. Table I provides an overview of the activities in which people temporarily appropriate public spaces. In the section which follows we will explore how these forms of activity take place within MCC, looking at specific examples from historical sources as well as from the present.

Table I:Activities in the public space related to temporary appropriation (Source: Lara-Hernandez, Melis \& Caputo, 2017).

\begin{tabular}{|c|c|c|c|c|c|c|}
\hline Category & \multicolumn{2}{|l|}{ Economy } & \multicolumn{3}{|l|}{ Leisure } & \multirow[b]{2}{*}{$\begin{array}{l}\text { Sacralisation } \\
\text { Any activity in which a } \\
\text { person or a group use the } \\
\text { public space for religious } \\
\text { purposes. }\end{array}$} \\
\hline Description & $\begin{array}{l}\text { Any activity in } v \\
\text { or group use th } \\
\text { in order to obt: } \\
\text { economic bene } \\
\text { indirectly. }\end{array}$ & $\begin{array}{l}\text { which a person } \\
\text { e public space } \\
\text { ain an } \\
\text { fit directly or }\end{array}$ & \multicolumn{3}{|c|}{$\begin{array}{l}\text { Any activity in which a person or a group } \\
\text { use the public space for leisure purposes. }\end{array}$} & \\
\hline Sub-category & Work & Trade & Sports-games & $\begin{array}{l}\text { Artistic } \\
\text { expressions }\end{array}$ & Rest & \\
\hline $\begin{array}{l}\text { Individual or } \\
\text { collective }\end{array}$ & $\begin{array}{l}\text { Advertising or } \\
\text { promoting } \\
\text { services, } \\
\text { waiting, } \\
\text { engaging or } \\
\text { attracting } \\
\text { possible } \\
\text { clients. }\end{array}$ & $\begin{array}{l}\text { Selling or } \\
\text { buying } \\
\text { products } \\
\text { (food, } \\
\text { handicraft, } \\
\text { clothes, etc.) }\end{array}$ & $\begin{array}{l}\text { Skateboarding, } \\
\text { soccer, cards, } \\
\text { marbles, } \\
\text { hopscotch. }\end{array}$ & $\begin{array}{l}\text { Playing music, } \\
\text { dancing, } \\
\text { painting, } \\
\text { acrobatics, } \\
\text { reciting and } \\
\text { singing. }\end{array}$ & $\begin{array}{l}\text { Eating, } \\
\text { resting }\end{array}$ & $\begin{array}{l}\text { Processions, praying, lighting } \\
\text { candles and putting flowers. }\end{array}$ \\
\hline
\end{tabular}




\section{The official use of the street in Mexico City Centre}

We analysed the laws and regulations approved by the government of Mexico City regarding the use of the street using document analysis (Bowen, 2009). In addition, in order to gather further information about how the street (as public space) is actually managed, an interview was conducted with the general coordinator of Autoridad del Centro Historico, aimed at collecting information on temporary appropriation and whether it is being considered at street management level.

\section{I Mexican laws and regulations regarding street use}

Several laws and regulations in Mexico City (Gobierno del Distrito Federal, 2016, 2015; Asamblea Legislativa del Distrito Federal III Legislatura, 2004; Gobierno del Distrito Federal, 2013; Gobierno de la Ciudad de México, 20l4) refer to the use of streets and the activities that are allowed to happen in them. Table 2 summarises the information found in Mexican laws and regulations.

In 2004, the Ley de la Cultura Civica del Distrito Federal (Law of the Civic Culture of Mexico City) was approved by the government, and establishes how citizens should behave in public spaces and neighbourhoods. The $15^{\text {th }}$ article of Chapter I/Second Title states that it will guarantee the harmony and coexistence of its inhabitants through the fulfilment of their duties, such as a) the freedom of people's actions in public spaces, and b) by allowing the proper use of public spaces according to their nature.

In 2013 a more specific law was approved: the Ley para el uso de las vías y los espacios públicos del Distrito Federal (Law for the use of streets and public spaces in Mexico City), which establishes the right to use and enjoy public spaces, especially streets that are used in different ways, rather than streets being just for motor-vehicles. Article 6 states that users of public space (including streets) have the right to use the property for common use according to its nature, and have the right to access, stay and transit in streets. Article 7 establishes that public space users have the duty to access, use, stay in, or transit through public space without disturbing other users. Both laws clearly refer to the social dimension of streets as public spaces.

Other laws, such as Reglamento de Transito del Distrito Federal (Transit Regulations of Federal District) and Ley de Movilidad de la Ciudad de Mexico (Law of Mobility of Mexico City) establish the free access, use and transit of pedestrians, cyclists and motor-vehicles in streets and roads. They also establish that streets should be free of obstacles or elements that impede or hinder pedestrian traffic, except in authorised cases. Both laws give priority to pedestrian movement; and they acknowledge different uses for the street beyond just movement.

Moving beyond laws aimed at traffic regulation and mobility, socio-urban researchers, such as Campos Cortes \& Brenna Becerril (2015) and Ramirez Kuri (20I0; Anon, 2016), argue that the codes compiled by planners and urban designers have focused on the economic development and formal aspects of the area, rather than including lessons from other fields dealing with social and cultural aspects. Urban design interventions have been implemented according to a master plan, titled Plan Integral de Manejo del Centro Histórico de la Ciudad de México (Management Plan for México City Centre), which involves pedestrianisation, change of pavement, sidewalk expansion, and the addition of urban furniture as well as lighting and trees. According to Flores Arias (2015), even though physical improvements of public spaces in MCC are the result of a plural approach 
(involving the opinion of the academic sector, government, experts and general population), they are implemented in a top-down manner, and as a result, do not represent the interests of the population (20I5). Though aesthetically pleasing for tourists and visitors, the urban design interventions conducted in MCC in conjunction with changes to the urban landscape (physical and social) have resulted in the eviction of urban actors, thus eliminating the lively social dynamics that they were contributing to(Campos Cortés \& Brenna Becerril, 20I5; Martinez-Ramirez, 20I5). These planning policies are just as significant for the use of public space as the laws cited in Table 2, and yet they are far less accessible and therefore less open to debate and to discussion.

\subsection{The view of the authorities on temporary appropriation}

As stated above, we conducted an interview with a key figure in the local city administration to collect a fuller picture of the official understanding of TA in the streetscape. The answers provided in Table 3 help to give a picture of the government's working policy on TA activities. On the one hand, it clearly shows that there is an aversion towards economic activities related to work, and particularly towards trade and commerce. On the other hand, activities related to leisure such as sports and games, artistic expression, resting, religious activities and pedestrian use are strongly welcomed. The single most striking observation to emerge from the data was that many of the activities which were reported as desirable could actually be categorised as obstacles for pedestrians, and consequently convene the official legal position. As a result there is some discrepancy between the written legal and the day-to-day official views regarding activities that are welcome to occur in the street in MCC.

\subsection{Summary}

The laws regarding the governance of Mexico City specify that public spaces (streets and squares) must be accessible for every citizen without any distinction or impediment (Gobierno del Distrito Federal, 2013). Mexican citizens have the right to appropriate public spaces and streets, and streets exist for more than just transit purposes. Furthermore, citizens must respect other street users and respect their rights to use the street area as they wish, so long as this does not impede pedestrian traffic or cause a disturbance of the peace. There is no specific mention of a ban or prohibition on commercial activity, or any further restrictions placed upon the types of activity which can peacefully be enjoyed, other than the vague reference to streets being used according to their nature.

This is not the way in which the authorities would like the street to be used. Official policy would rather that commercial activities be restricted, and that the street be primarily used for transit and leisure. Maintaining pedestrian access was not a priority, and some of the activities that were given preference would directly impede pedestrian traffic. This is supported by official urban planning policies, which give preferential treatment to the tourist experience of MCC and often disregard the needs of local residents and habitual users of the street area who rely on this space to conduct activities central to their day-to-day life. 
Table 2: Laws and Regulations about the use of streets in Mexico City (translations:Authors)

\begin{tabular}{|c|c|c|c|c|c|}
\hline \multicolumn{6}{|c|}{ Laws and Regulations } \\
\hline 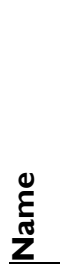 & $\begin{array}{l}\text { Law for the use of } \\
\text { streets and public } \\
\text { spaces in Mexico City } \\
\text { (Gobierno del Distrito } \\
\text { Federal, 2013) }\end{array}$ & $\begin{array}{l}\text { Law of the Civic } \\
\text { Culture of } \\
\text { Mexico City } \\
\text { (Asamblea } \\
\text { Legislativa del } \\
\text { Distrito Federal III } \\
\text { Legislatura, 2004) }\end{array}$ & $\begin{array}{l}\text { Law of Mobility of } \\
\text { Mexico City } \\
\text { (Gobierno del } \\
\text { Distrito Federal, } \\
\text { 2016) }\end{array}$ & $\begin{array}{l}\text { Transit } \\
\text { Regulations of } \\
\text { Federal District } \\
\text { (Gobierno del } \\
\text { Distrito Federal, } \\
\text { 20I5) }\end{array}$ & $\begin{array}{l}\text { Citizen } \\
\text { Manual for } \\
\text { the care of } \\
\text { City Centre } \\
\text { (Gobierno de la } \\
\text { Ciudad de } \\
\text { México, 20I4) } \\
\end{array}$ \\
\hline 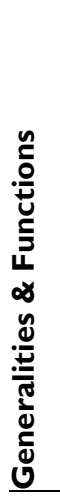 & $\begin{array}{l}\text { Stabilised the right to use } \\
\text { and enjoy the public space, } \\
\text { including streets used in a } \\
\text { different way rather than for } \\
\text { motor-vehicles. The public } \\
\text { space is considered as an } \\
\text { ambience or scenery of } \\
\text { social integration, where the } \\
\text { right of association and the } \\
\text { right of the others to use the } \\
\text { same space, its appropriation } \\
\text { (accessibility, permanence } \\
\text { and enjoyment) of the space, } \\
\text { the collective space, the } \\
\text { space for everybody. }\end{array}$ & $\begin{array}{l}\text { It establishes the } \\
\text { minimum rules of } \\
\text { citizen behaviour. }\end{array}$ & $\begin{array}{l}\text { It dictates the laws for } \\
\text { mobility purposes in } \\
\text { Mexico City. }\end{array}$ & $\begin{array}{l}\text { It regulates the use of } \\
\text { streets and roads of } \\
\text { Mexico City. }\end{array}$ & $\begin{array}{l}\text { It is a manual for } \\
\text { citizens that use } \\
\text { MCC. }\end{array}$ \\
\hline 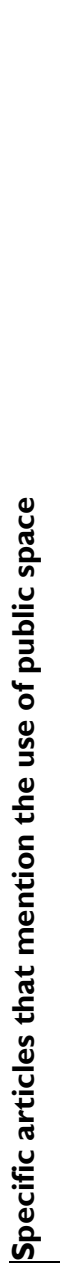 & $\begin{array}{l}\text { Art } 7 . \text { The duties of the } \\
\text { users are: I. To use the } \\
\text { public space and streets } \\
\text { according to their nature and } \\
\text { destination: II. To exercise } \\
\text { their rights without } \\
\text { disturbing the order and } \\
\text { public peace, or affecting the } \\
\text { developing continuity of } \\
\text { other inhabitants' activities. }\end{array}$ & $\begin{array}{l}\text { Second Title of the } \\
\text { Civic Culture and } \\
\text { neighbour's } \\
\text { participation. Chapter } \\
\text { I. Art I5. The Civic } \\
\text { Culture in Mexico } \\
\text { City, which guarantees } \\
\text { the harmonious } \\
\text { coexistence of its } \\
\text { inhabitants, is based } \\
\text { on the fulfilment of } \\
\text { the following citizen } \\
\text { duties. VI. To allow } \\
\text { the freedom of action } \\
\text { of people in public } \\
\text { spaces and streets. X. } \\
\text { Make proper use of } \\
\text { public goods, spaces } \\
\text { and services according } \\
\text { to their nature and } \\
\text { destination. }\end{array}$ & $\begin{array}{l}\text { Art } 5 \text {. Mobility is the } \\
\text { right of every person } \\
\text { and the community to } \\
\text { carry out the effective } \\
\text { movement of individuals } \\
\text { and goods to access } \\
\text { through the different } \\
\text { modes of transportation } \\
\text { recognized in the Law, a } \\
\text { mobility system that } \\
\text { conforms to the } \\
\text { hierarchy and principles } \\
\text { that are established in } \\
\text { this order, to meet their } \\
\text { needs and full } \\
\text { development. In any } \\
\text { case, the object of the } \\
\text { mobility will be the } \\
\text { person. } \\
\text { Art I3. For the } \\
\text { fulfilment of the present } \\
\text { Law and the ordinances } \\
\text { that emanate from it, } \\
\text { Public Security will have } \\
\text { the following } \\
\text { attributions: } \\
\text { III. Maintain within the } \\
\text { scope of its powers, that } \\
\text { the road is free of } \\
\text { obstacles and elements } \\
\text { that impede, hinder or } \\
\text { impede vehicular and } \\
\text { pedestrian traffic, except } \\
\text { in only authorized cases, } \\
\text { in which case, as far as } \\
\text { possible, they should not } \\
\text { obstruct the accesses } \\
\text { for persons with } \\
\text { disabilities. }\end{array}$ & $\begin{array}{l}\text { Art. I. The purpose of } \\
\text { these regulations is to } \\
\text { regulate the } \\
\text { circulation of } \\
\text { pedestrians and } \\
\text { vehicles on public } \\
\text { roads and road safety } \\
\text { in Mexico City. Art. } \\
\text { 6.- The Public } \\
\text { Administration will } \\
\text { provide the necessary } \\
\text { means for people to } \\
\text { freely choose the way } \\
\text { to move in order to } \\
\text { access the goods, } \\
\text { services and } \\
\text { opportunities offered } \\
\text { by the City. The level } \\
\text { of vulnerability of } \\
\text { users, the externalities } \\
\text { generated by each } \\
\text { mode of transport and } \\
\text { their contribution to } \\
\text { productivity will be } \\
\text { considered for the } \\
\text { establishment of public } \\
\text { policy in this area. } \\
\text { Priority will be given } \\
\text { to the use of road } \\
\text { space and the } \\
\text { distribution of } \\
\text { budgetary resources } \\
\text { will be assessed } \\
\text { according to the } \\
\text { following hierarchy of } \\
\text { mobility: } \\
\text { I. Pedestrians }\end{array}$ & $\begin{array}{l}\text { Chapter 7. Use } \\
\text { and conservation } \\
\text { of public spaces. } \\
\text { Conditions for } \\
\text { realising cultural } \\
\text { activities. First, } \\
\text { permission must } \\
\text { be granted by the } \\
\text { SSPDF (Secretary } \\
\text { of Public Safety of } \\
\text { Mexico City), the } \\
\text { SGDF (Mexico } \\
\text { City Council) and } \\
\text { Autoridad del } \\
\text { Centro Historico. }\end{array}$ \\
\hline
\end{tabular}


Table 3: Questionnaire response from Autoridad del Centro Historico.

\begin{tabular}{|c|c|c|c|c|c|}
\hline \multicolumn{6}{|c|}{ To what extent is it desirable for these activities to happen on the street? } \\
\hline Activities & $\begin{array}{l}\text { very } \\
\text { desired }\end{array}$ & $\begin{array}{l}\text { moderately } \\
\text { desired }\end{array}$ & somewhat & $\begin{array}{l}\text { minimally } \\
\text { desired }\end{array}$ & not at all \\
\hline Work & 5 & 4 & 3 & $z$ & I \\
\hline Trade & 5 & 4 & 3 & 2 & + \\
\hline Sport/games & 5 & 4 & 3 & 2 & I \\
\hline Artistic expressions & 5 & 4 & 3 & 2 & I \\
\hline Rest & 5 & 4 & 3 & 2 & 1 \\
\hline Religious activities & 5 & 4 & 3 & 2 & 1 \\
\hline Pedestrian use & 5 & 4 & 3 & 2 & 1 \\
\hline \multicolumn{6}{|l|}{ Demographic study } \\
\hline Do you live in MCC? & & & & $(y)$ & (n) \\
\hline Do you work in MCC? & & & & $(\#)$ & (m) \\
\hline $\begin{array}{l}\text { Do you live in San } \\
\text { Jerónimo St? }\end{array}$ & & & & (y) & (n) \\
\hline $\begin{array}{l}\text { Do you work in San } \\
\text { Jerónimo St? }\end{array}$ & & & & (y) & (f) \\
\hline Do you live in Moneda St? & & & & (y) & (n) \\
\hline $\begin{array}{l}\text { Do you work in Moneda } \\
\text { St? }\end{array}$ & & & & (y) & (f) \\
\hline
\end{tabular}

\section{Appropriation of streets in Mexico City Centre}

3.I Mexico City Centre: historical use

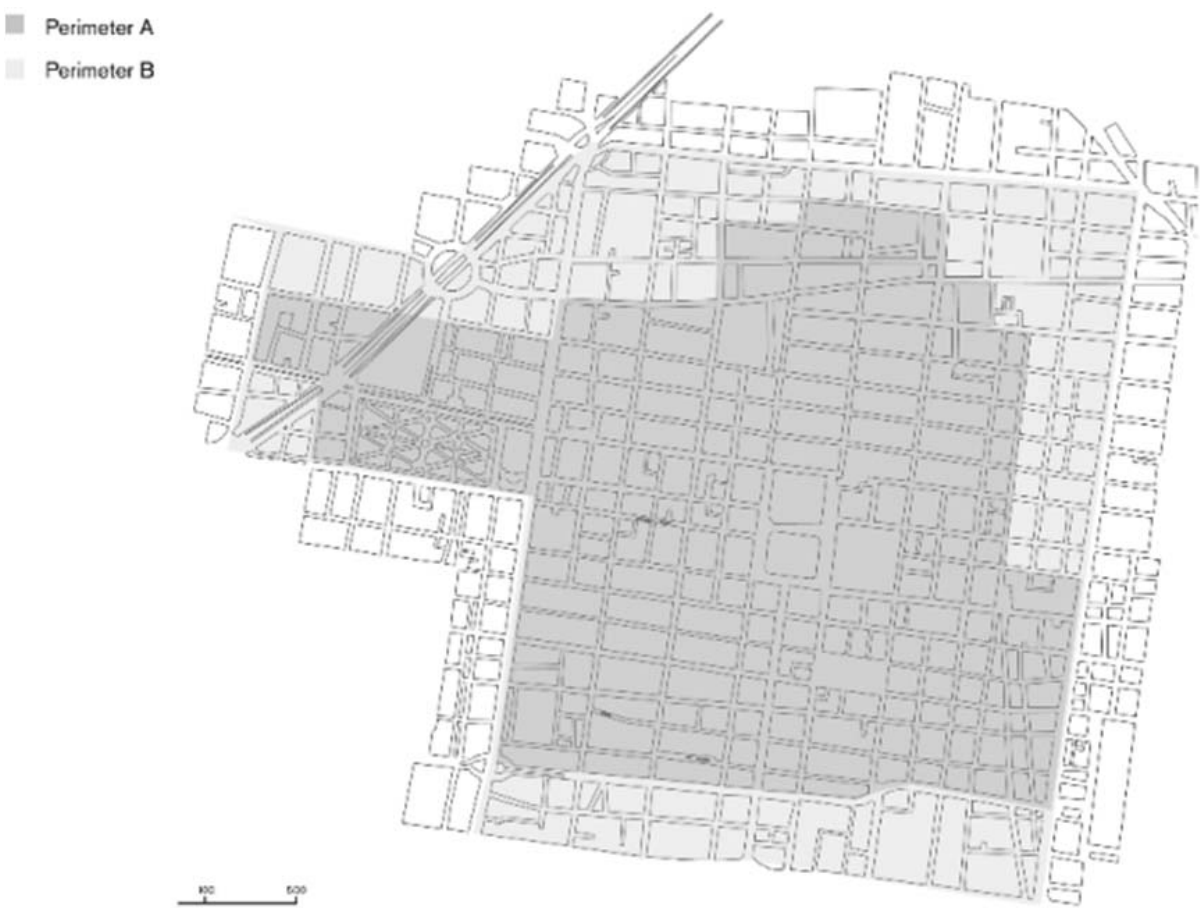

Figure I: MCC perimeters (source: Autoridad del Centro Historico, 20I I) 
Mexico City Centre (MCC) is the biggest colonial historic centre in America, with a total area of $9.1 \mathrm{~km}^{2}$ and a population of 6I,22 (INEGI, 20I8). In terms of planning, MCC has the Spanish grid commonly used in Latin American colonies, starting from the main square, the church and the council building (see

Figure I). The streets of Mexican cities are public spaces that are key for urban life, even prior to the Spanish colonisation. The pre-Hispanic civilisations were characterised by the intensive utilisation of the outdoor spaces for everyday activities (Keller, 2006; Suárez Pareyón, 2004). The Aztecs founded the city of Tenochtitlan, the urban pattern of which was compounded by blocks, streets and channels. The Aztecs used the channels for communication purposes, while streets were reserved for a diversity of activities such as trade, leisure, religious celebrations and even sacrifices (Leon Portilla, 1995). The public spaces in which the social, political, economic and religious lives of people occurred were the streets (Webster \& Sanders, 200I). Informal activities were an essential element of street life in Tenochtitlan, especially for the common people, as shown in Figure 2 (Crossa, 2009).

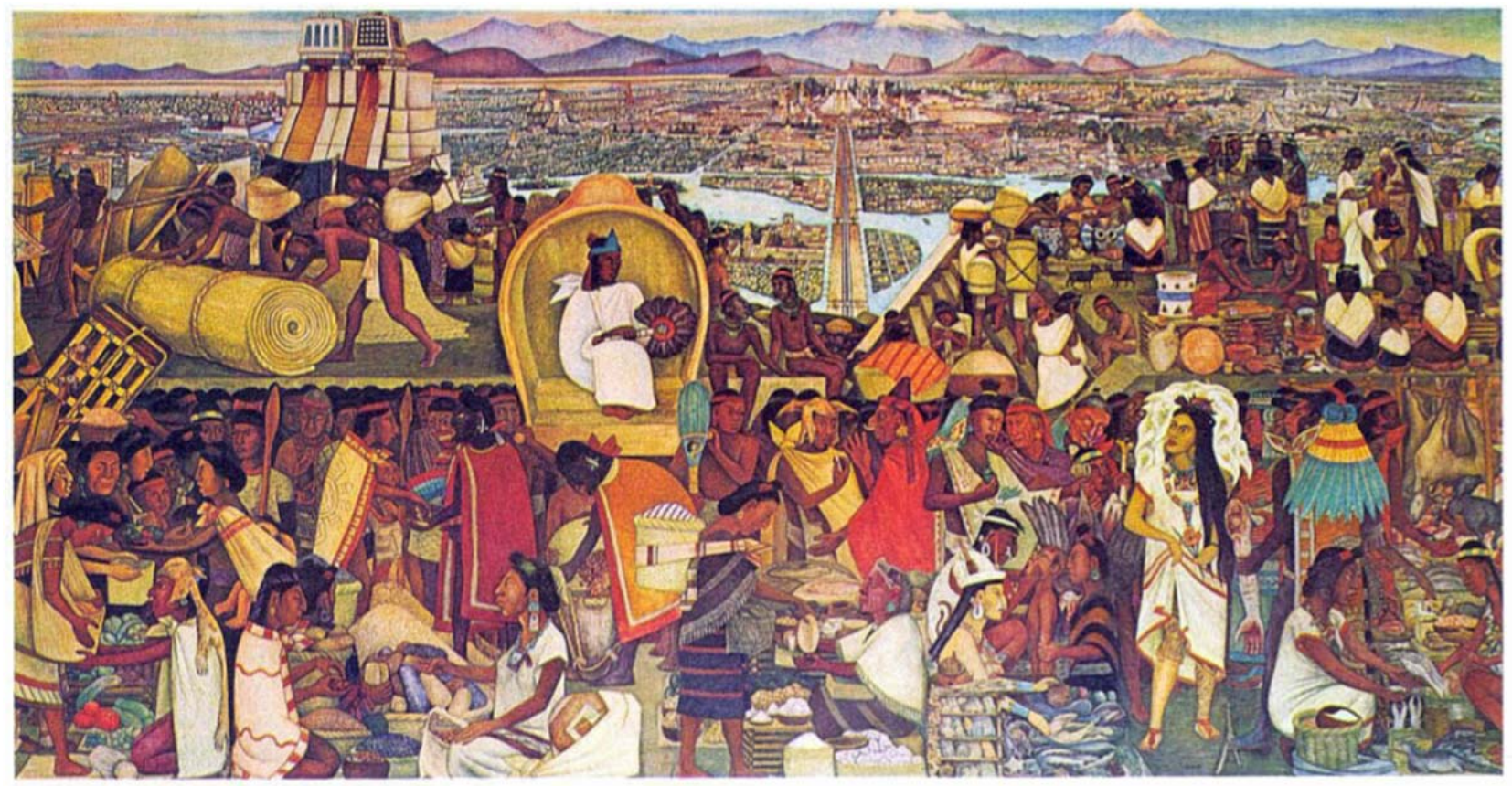

Figure 2: The great Tenochtitlan, mural by Diego Rivera Exhibited in the Palacio Nacional in Mexico City (source: Rivera, 1945)

In the 16th century, during the Spanish colonisation, a new urban planning pattern was established over Tenochtitlan, transforming the city (Stanislawski, 1947). The conquerors tried to regulate informal activities (trading, playing, religious expressions) that happened on each specific street for each activity with a singular order (Nelson, 1963), by confining them into specific places, such as squares in the Spanish tradition. They succeeded for a short period of time, but as the city grew, the confinement of informal activities was not viable anymore. As Monnet (1995, 1996) and Portal (2009b) describe, this informality is still palpable in the streets of MCC, and is easily visible to observers. 


\subsection{Mexico City Centre: the current situation}

In 1987, UNESCO declared MCC a world heritage site. Although the declaration has triggered a process of urban design transformation intended to beautify the built environment, Diaz Parra (2014), Oehmichen (2010), and Ramirez Kuri (2015) have pointed out that this has not necessarily led to the planned improvements urban life, and has occurred to the detriment of the TA of public spaces. Hiernaux-Nicolas (2005) suggests that there has been a symbolic privatisation of heritage in favour of the dominant class and commercial recovery, challenging the strategies promoted by the entrepreneurial urban governance and in doing so creating counter-spaces. As an example of this, one of the strategies of the transformation program was the removal of street vendors from perimeter $A$ (see map in

Figure I) (Autoridad del Centro Historico, 20I I). As a result of this action, the use of public spaces in MCC has changed, with a collateral effect on the relationship between urban design and TA of public spaces. As part of our research into the use of public space (Lara-Hernandez, Melis \& Caputo, 2017; Lara-Hernandez \& Melis, 2018) photographs were taken in MCC during 2017 showing different activities taking place in the street and in public squares. Many of these activities clearly show public space being temporarily appropriated by members of the public, and fall into the three categories discussed previously. We also found instances of official use of public space which fell under TA, as well as activities which were unexpected, and which defied our original categorisation. The three main categories, as well as the outliers, will be discussed in turn below.

\subsection{Economic actions and temporary appropriation}

Looking at economic forms of temporary appropriation, there is evidence of disruption or disarrangement to the everyday practices of residents, indigenous artisans, and many local vendors, impacting directly on the economy of many families. This has altered the traditional Mexican way of living in cities, which even before the Spanish colonisation was and is about socialising and trading outdoors. According to Crossa (2009), even though the strategies implemented by MCC's Programa de Rescate have attempted to remove informal commerce from streets, street vendors have found ways to resist, and they have become toreros (a term referring to Mexico City's nomadic vendors), and they are still working in the area. For instance, street vendors in Moneda St. place their merchandise on a cloth on the ground that can easily be gathered up if necessary (see Figure 3 left). A "guardian" with a walkie-talkie is constantly looking out for the presence of authorities (see Figure 3 right). Once the "guardian" has spotted the authorities he notifies the street vendors who immediately collect their merchandise and go and hide in a building nearby (see Figure 4 left). In a matter of seconds the whole temporary market has vanished (see Figure 4 right). 

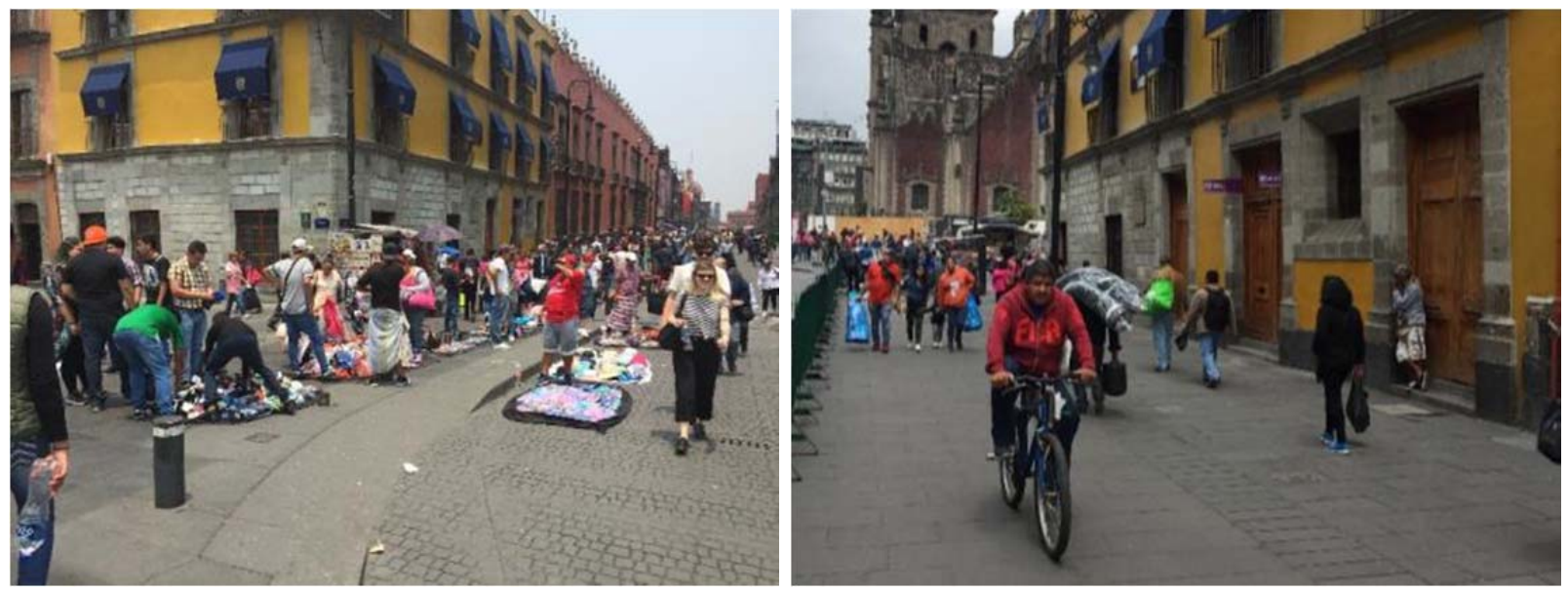

Figure 3: Street vendors in Moneda St. (left),

Street vendors' guardian with walkie-talkie (right) (Source: Authors)
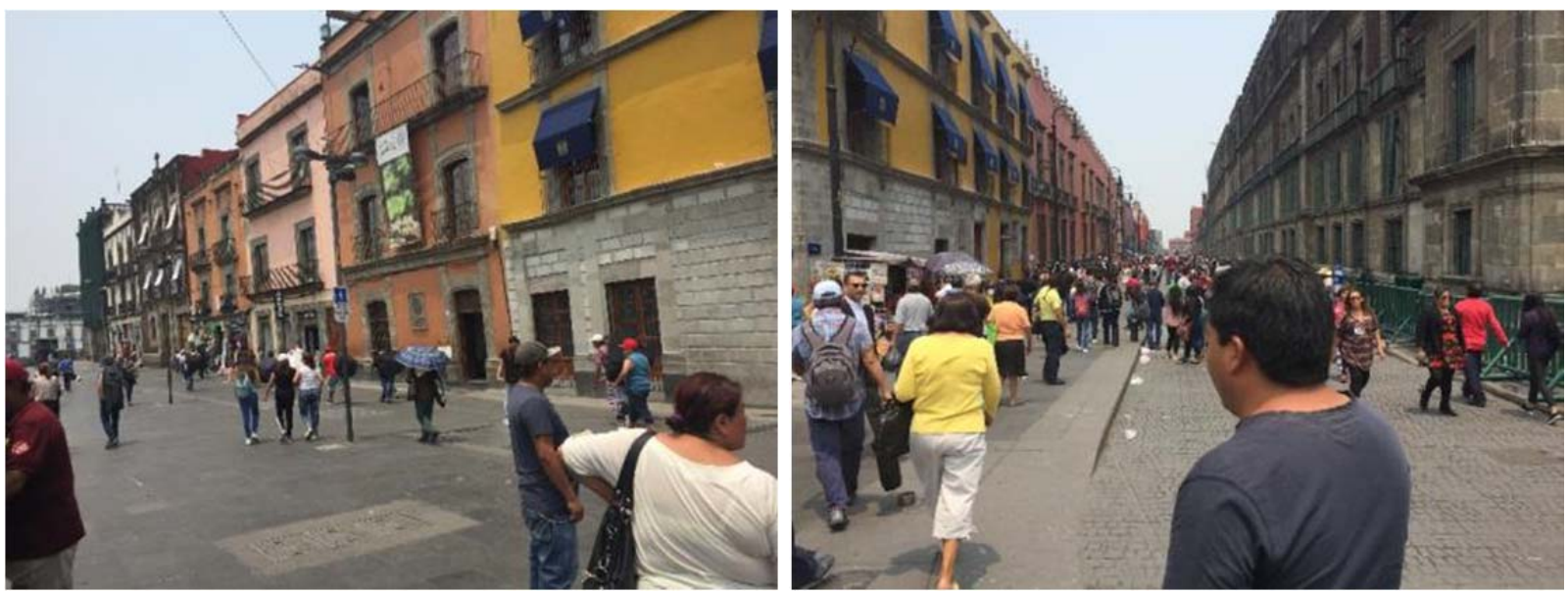

Figure 4: Street vendors hiding in buildings nearby (left).

Street vendors have left the street (right) (source: Authors)

As we have seen, the law regarding street use in MCC primarily protects the rights of pedestrians to have access to the street for transit. In further examples of commercial driven TA, citizens as both consumers and entrepreneurs have found ways to work around the law, for example by placing small chairs and tables right next to the edge of a building (see Figure 5 left). The street which remains a viable place for transit thus simultaneously also becomes an open-air dining area. Similarly, in the example illustrated in Figure 5 (right), a hair treatment is being carried out using a bollard as a hairdresser's chair, with the street becoming briefly an urban salon.

Moreover, even employees of governmental institutions such as the police or refuse collectors temporarily appropriate the street for their own purposes. Figure 6 (left) shows police officers holding their morning meeting in the street, while Figure 6 (right) shows a line of refuse collectors lining up to receive their weekly payment. In both of these examples people temporarily appropriate the street, using the space as an urban open office. 

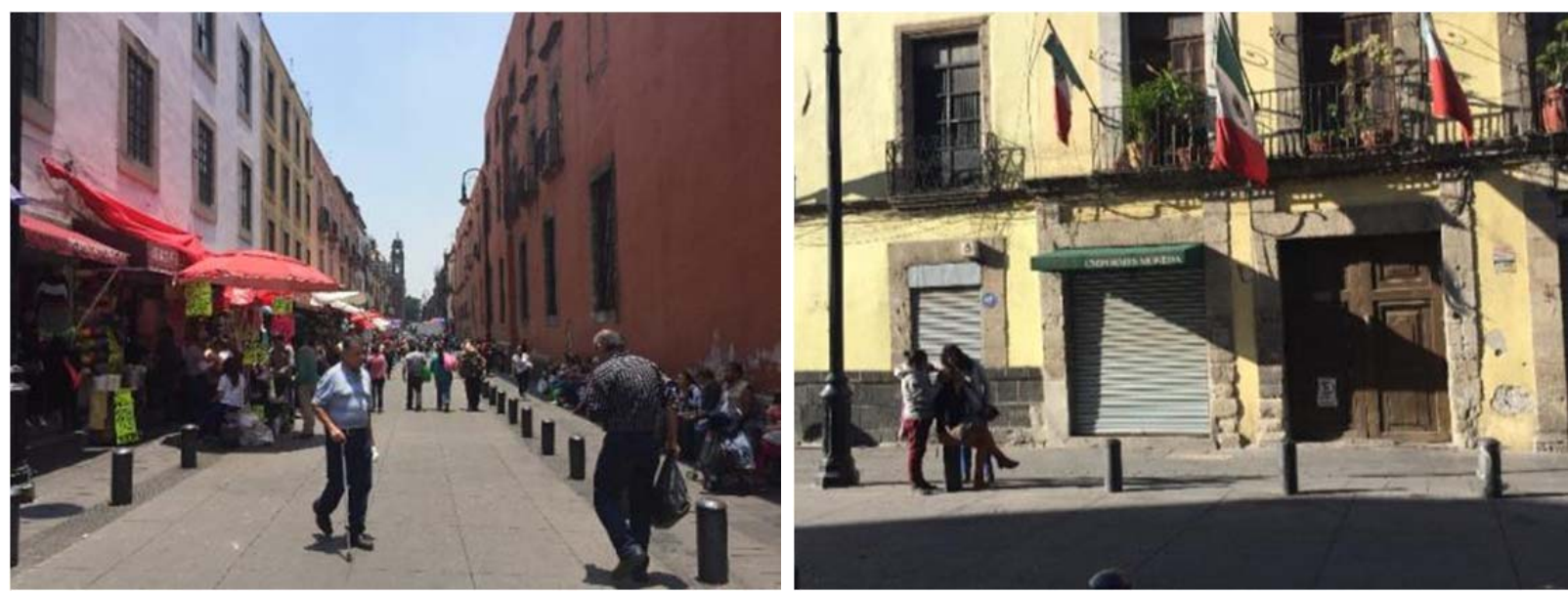

Figure 5: People eating on the street (left), woman doing hair treatment on the street (right) both in Moneda St. (source: Authors)
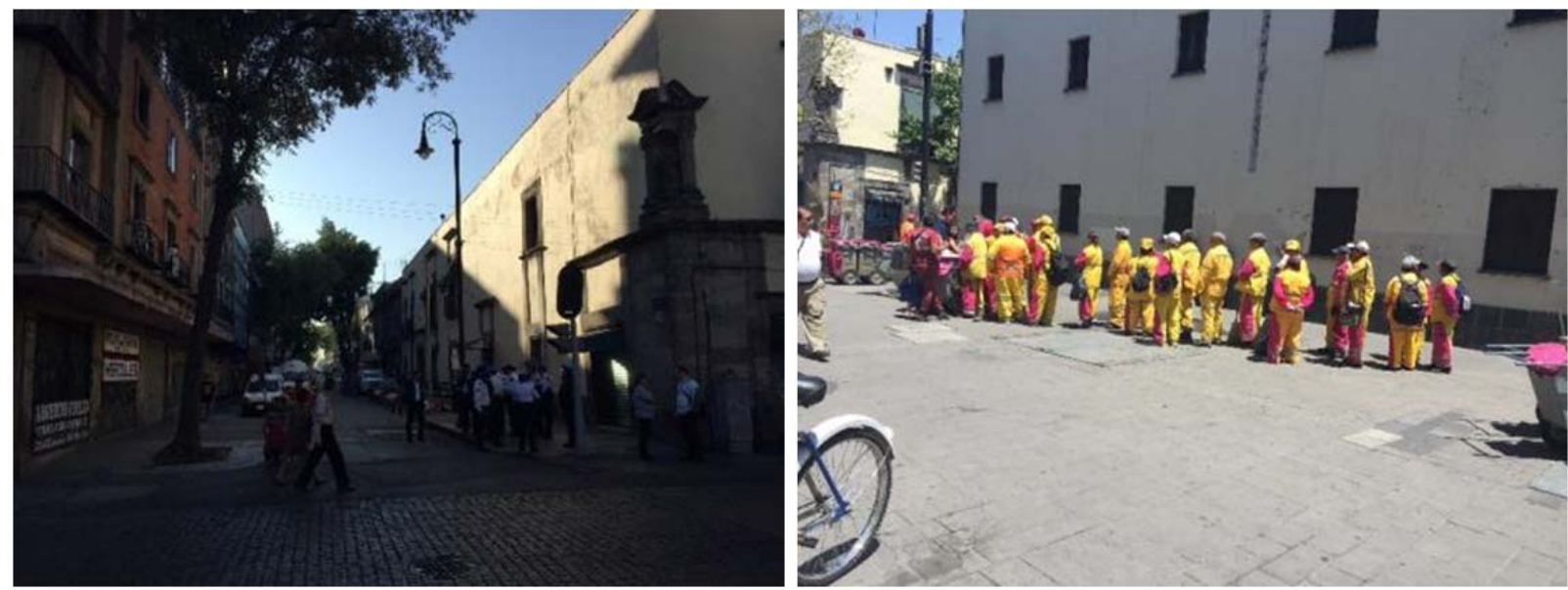

Figure 6: Police officers in an ordinary morning meeting (left), refuse collectors getting their weekly payment (right) both in San Jeronimo St. (source: Authors)

\subsubsection{Leisure and temporary appropriation}

Looking at leisure activities, Delgadillo (2014) describes the planning policies that have been implemented as part of the urban beautification process. La Alameda Central (the largest park in MCC), used to be appropriated by families, minority groups, religious groups, mimes and even musicians. After the urban design transformation that took place in 20I3, this type of appropriation is not happening anymore (Martinez-Ramirez, 20 I5). The new policies allow the government to displace users who are perceived to be informal, suspicious or misbehaving; to pursue an official cultural programme of free cultural and leisure events which prevent the free use and public dimension of this space; and to follow a zero-tolerance agenda, including an increase in police officers and surveillance in the area (Delgadillo, 2014).

In contrast to the traditional, family-centric and group-oriented use of the street, many of the examples of leisure related TA that we observed in MCC were more individual in nature. In the examples shown in Figure 7 we see a man napping and a woman knitting; two individuals make use of a small peripheral area at the edge of a street or square, and 
their chosen activity does not invite interaction with the wider public. Figure 8 shows more complex use of the street area, and highlights how TA can take multiple forms, in this case both economic and leisure-based. In the left hand picture a workshop takes place outside a church, in the right hand picture a woman is playing the violin in the street. Although both of these activities could plausibly be primarily economic in nature, their ability to be enjoyed or participated in by the wider public extends them beyond merely commercial forms of TA.
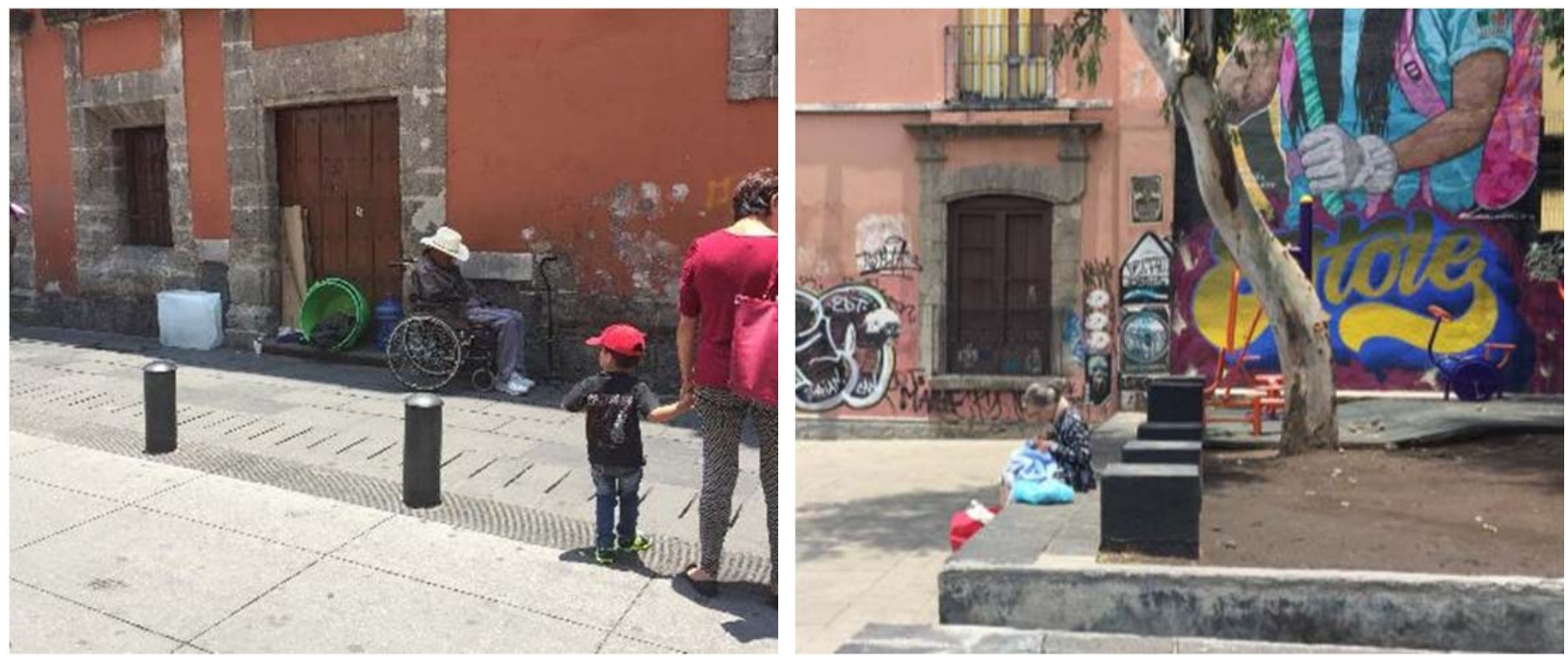

Figure 7: Man in wheelchair taking a siesta (left), Woman knitting (right) (source: Authors)
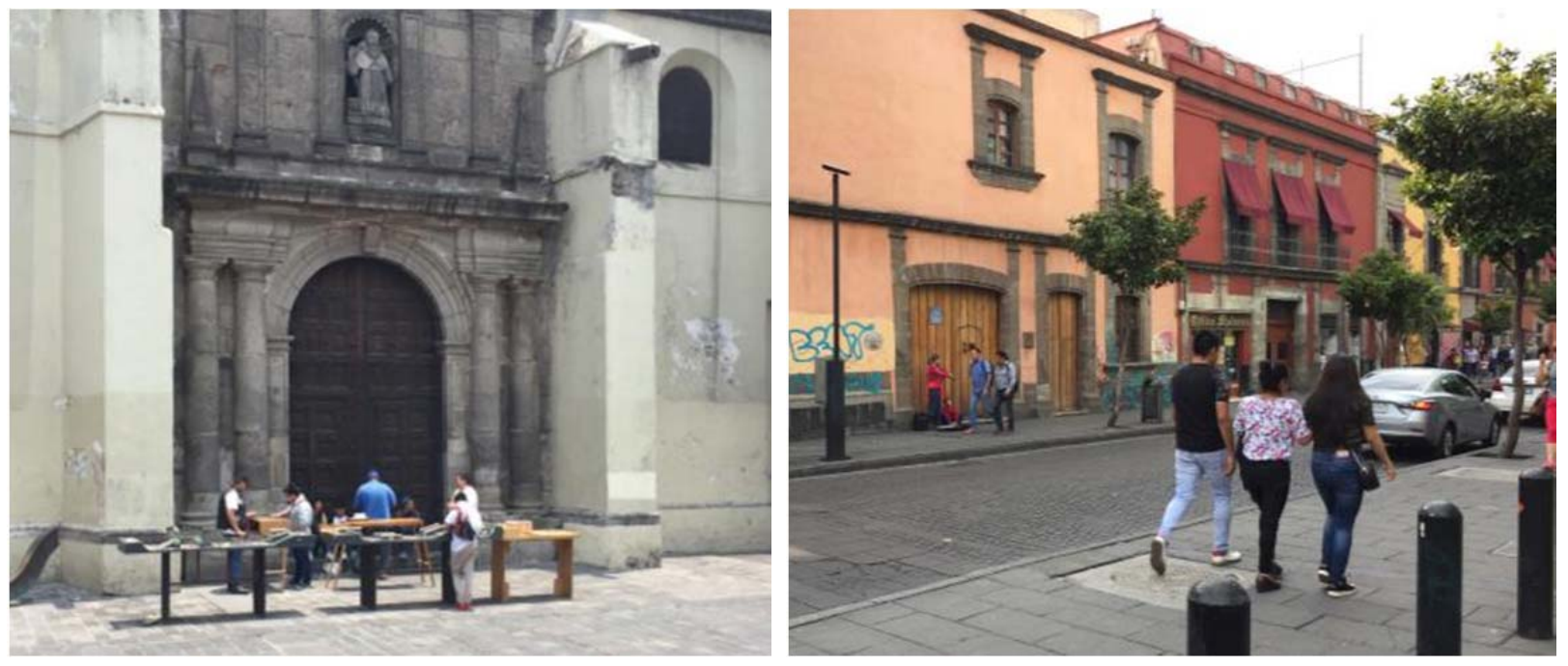

Figure 8: Open-air workshop (left) woman playing the violin (right) (source: Authors)

\subsubsection{Sacralisation and temporary appropriation}

The third category of TA that we expected to find in MCC relates to religious activities. Whilst we observed traditional street altars occupying space within the street (see Figure 9), we also found unexpected instances of TA which could be categorised under sacralisation. The celebration of Día de los Muertos (day of the dead) in Mexico is a wellknown as a family gathering to remember deceased family and friends. It is a national 
celebration in which the whole community participates. Although prostitution is a practice which is not commonly associated with family values, the prostitutes of $L a$ Merced (a neighbourhood adjacent to MCC) gather together on this day and make their own public ofrenda (Castrejon-Arcos, 20I2; Redacción ADN, 20I5). Figure 10 illustrates how despite the laws, regulations and the social stigma, the prostitutes of La Merced temporarily appropriate the street to celebrate Día de los Muertos.

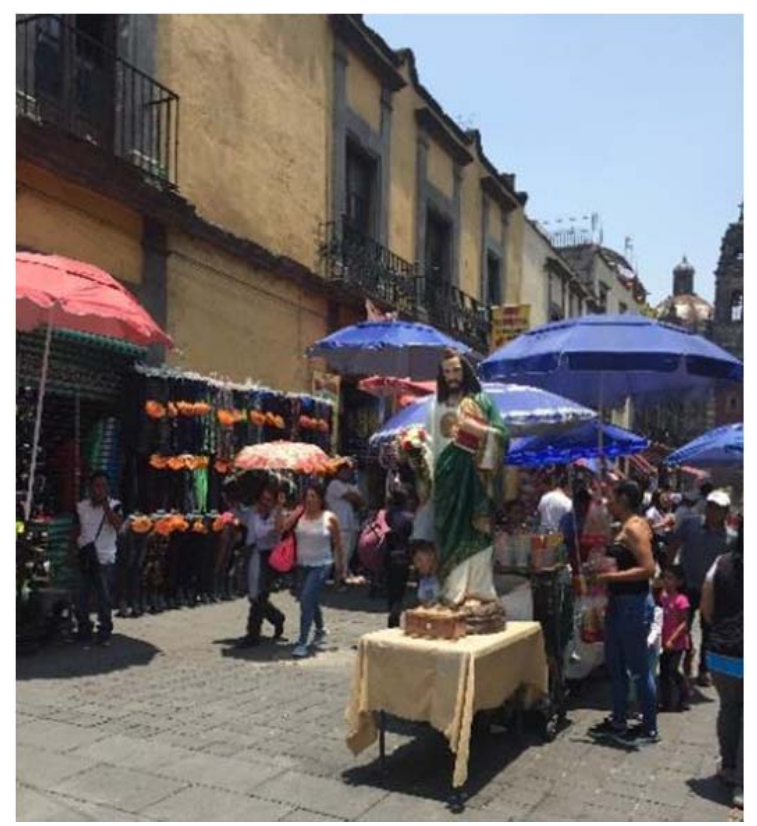

Figure 9: Street altar in Mexico City Centre (right) (Source: Authors).
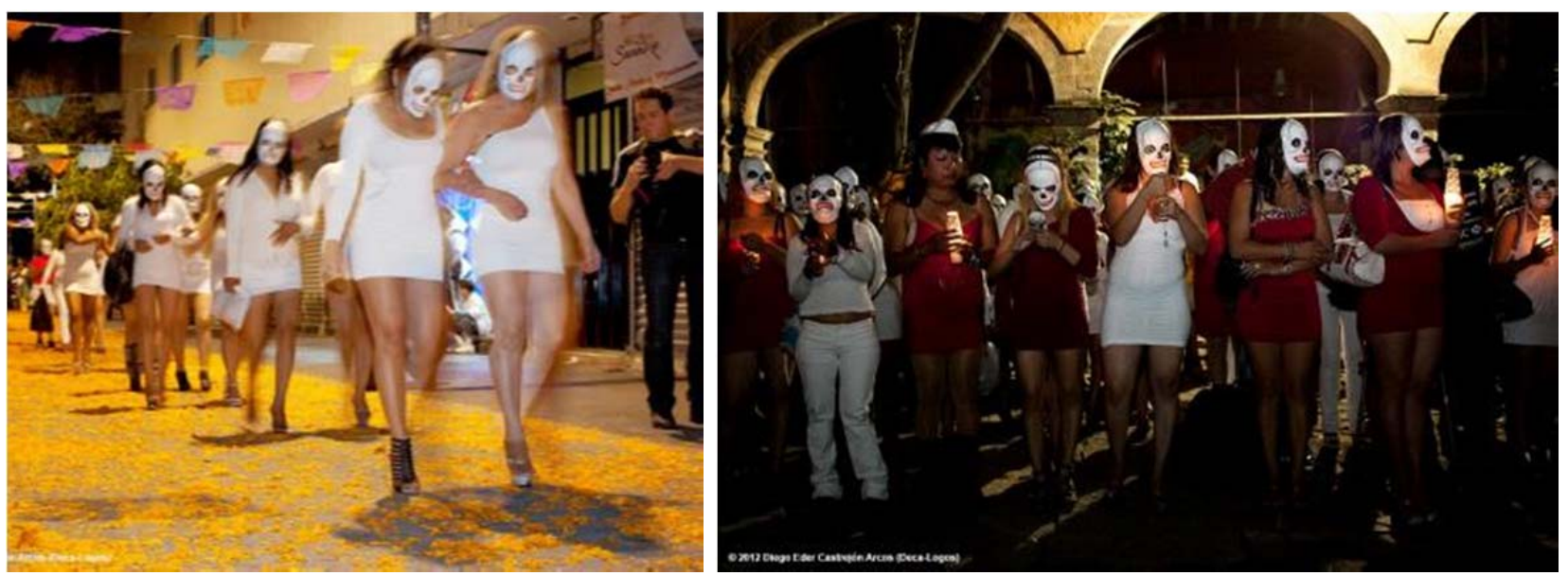

Figure 10: Prostitutes celebrating Dia de los Muertos in La Merced (source: Castrejon-Arcos, 20I2)

\subsubsection{Other categories of temporary appropriation}

Although our previous work had suggested three definitive categories for TA, we found other examples of street use in MCC that did not fit neatly into any of these categories. Firstly, we observed that some health institutions temporarily appropriate the street, providing their services in the open-air for the benefit of the citizens (see Figure II). Another example are the daily protests that take place in Mexico City (see Figure I2). 
Between 2015 and 2017 there were more than ten thousand protest events registered by Secretaria de Seguridad Publica (City Security Department) and Secretaria de Gobierno (City Council), an average of nine protests every single day (Arredondo, 2018). By law (Gobierno del Distrito Federal, 20l3) citizens willing to take part in a protest utilising the public spaces (squares or streets) must to give notice to the authorities 72 hours prior the event. The authorities however state that just over half of these events receive advance notification, highlighting how the citizens' use of public spaces is embedded as a right in the context of Mexico City.
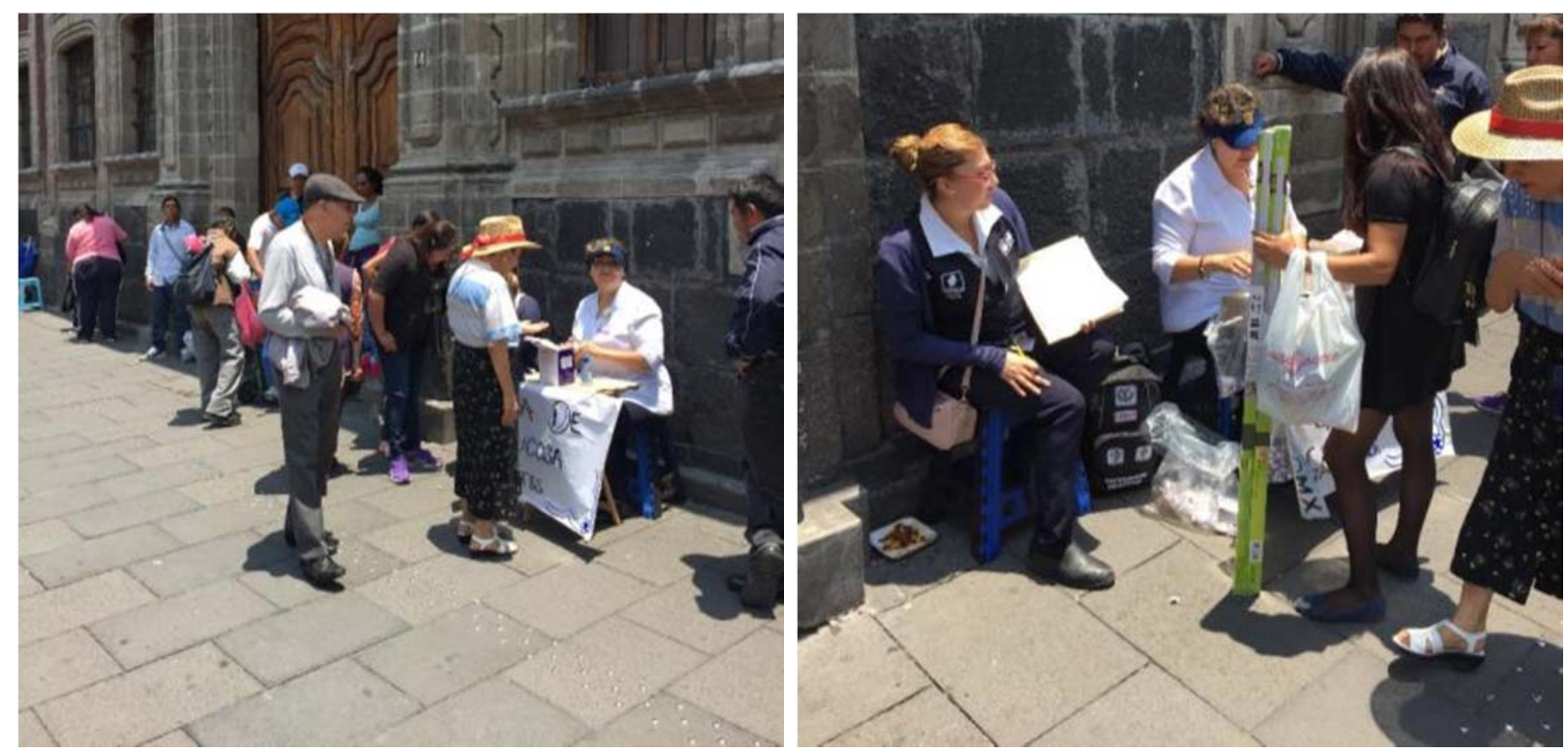

Figure I I: Nurses conducting tests to diagnose diabetes (source: Authors)

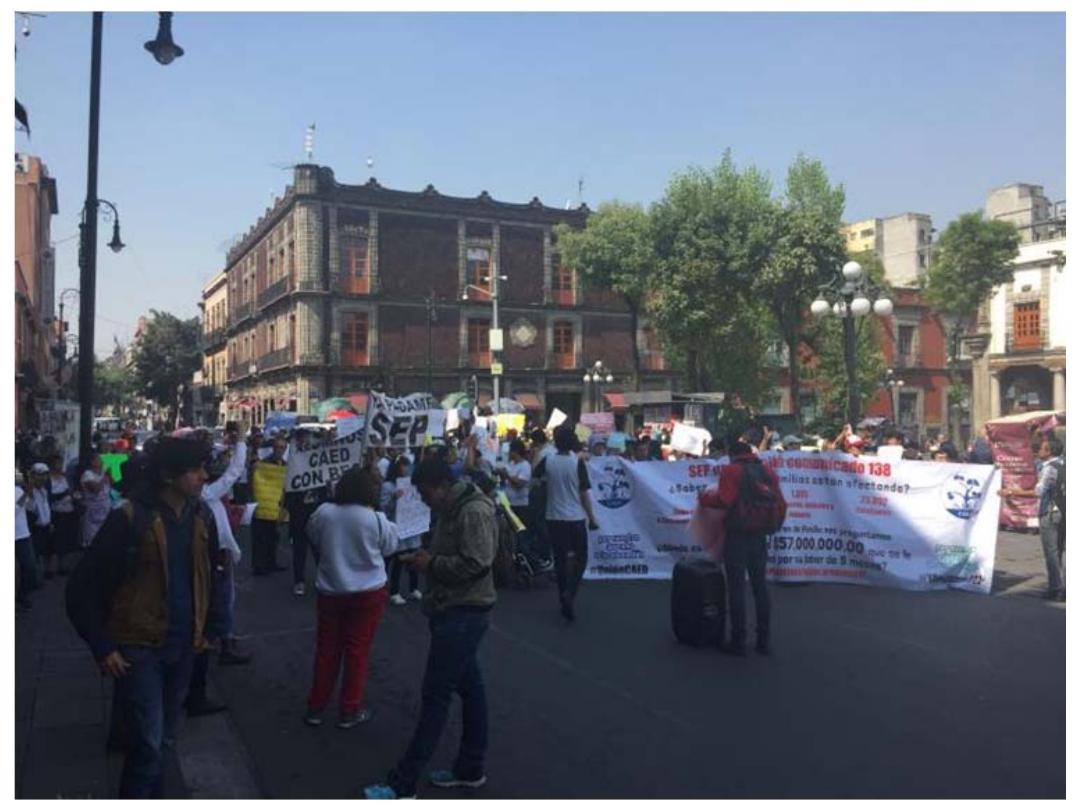

Figure 12: Protest against the education bill (Source: Authors) 


\section{Discussion}

\section{I Temporary appropriation of the street, and the laws and regulations of MCC}

As mentioned in the conceptual discussion, certain activities occurring in public spaces are considered TA, playing a key role in creating the bond between people and places, and consisting broadly of activities relating to commerce, leisure and religion. The current economic situation in MCC, whereby the built environment has been maintained and improved, may have had a positive impact on the tourist experience, but has arguably had a less favourable impact on everyday socio-urban conditions, which according to Van der Aa (2005), is a condition of many other heritage sites worldwide.

Some authors (Ramirez Kuri, 2008; Saraví, 2008; Alessandri Carlos, 2014) claim that planning regulations imposed on the use of public space are putting the inclusive and pluralistic nature of these spaces at risk. This situation poses a threat to the TA of public spaces, which according to Purcell (2002), is one of the key ways for citizens to exercise their right to the city. A space that is not formally equal for everyone can hardly enhance participation in solving fundamental urban issues such as diversity, governance, and inclusion. What is significant here is that the legislation that governs the use of the street in MCC is fairly loose, reserving only the right for pedestrian transit and maintaining the peace. In addition to this, the right to temporarily appropriate public space is tacitly recognised as a right in all of the laws and regulations that we reviewed. It is not until we begin looking at internal policy and communication that the discussion around appropriate and desirable forms of TA begins to emerge. The city's urban regeneration plan clearly focuses on leisure activities as the key driver of activity in the area, with as much of a stress on maintaining the historic centre for visitors to view and appreciate as for the local population to enjoy. Furthermore, our interview with director of a governmental institution showed that activities related to leisure and religion were considered desirable, whilst commercial activity was to be discouraged, even though the demographic section of the questionnaire shows that the respondent is fully aware of the urban dynamic happening in the area. In contrast to the arguments made by Janoschka and Sequera (20I4), Delgadillo (20I4) and Ramirez-Kuri (20I5; 20I6) that regulations have been imposed on public spaces that hinder TA we have instead found that the regulations themselves are vague and lack definition, and that it is internal planning policies, that come under far less public scrutiny, which are forming the backbone of the effort to modify street use in the area.

\subsection{The changing use of the street}

Although the use of public space is changing, it is significant that the urban actors have not been totally evicted, rather the way in which they temporarily appropriate the streets has changed. Whilst we observed the expected categories of economic, leisure and religious activities, we saw this appear in unexpected ways, as well as ways which we were unable to fit into these categories. We observed how TA is not only occurring in the acts of private citizens, but also in a semi-official context. Police meetings, governmental staff pay queues, and publicly administered healthcare were all observed happening in the street. Likewise we were surprised to observe acts of TA from groups that would otherwise be considered controversial, but which were permitted within a specific time or context. The example of the prostitutes celebrating on Dia de los Muertos highlights just how flexible the boundaries of TA can be, whilst the use of the street area for public protests 
reinforces what we found in the legislation, that citizens have the right to appropriate public space as long as they do so peacefully and preserve pedestrian access.

The legislation that we surveyed was not particularly specific on how the public may make use of the street, although internal governmental policies on street use were much clearer. Similarly the finding that around half of public protests do not notify the authorities in advance, but apparently without any issues, suggests that where TA is concerned there is a form of legal pluralism occurring in MCC, where state law, religious law, indigenous law, customary laws and local conventions all co-exist, and combine to govern the actual use of the street. In such plural realm the law of the state is not necessarily the dominant one. Furthermore, the state might not actually have the capacity to enforce the law (McAuslan, 2006). In this scenario customary law could have much more influence on how activities are conducted in public, with the written law, conventionally taken as formal, being considered informal and beneath consideration in practice.

The key finding from our research is that although activities were occurring that might strictly be considered illegal, nothing was happening that did not respect the spirit of the law. Informal commerce respected the requirements of pedestrian traffic, prostitutes celebrated a national holiday without disturbing the peace, political views were shared and governmental meetings were held in the same public arena and no one visibly questioned the right for the street to be used in any of these ways. Although some activities were deemed more desirable than others, there is no official consensus on the limits of permitted TA within MCC, and the streets continue to be used for a wide range of activities as a result.

\section{Conclusion}

This paper has shown that TA of the street is crucial for maintaining socio-urban dynamics in the contemporary city. Looking at the literature on TA we attempted to compartmentalise activities consisting of TA in MCC into three specific groups: economic actions, leisure activities and religious practices, however the full range of activities occurring within the street area were much wider than this and extended to include political activity, healthcare practices, and official governmental business. Compared with the legal position, which made no specific mention of permitted activities, and regeneration policies that indicated that informal commercial activity was undesirable, the day-to-day use of the street appears to reflect the practical needs and wants of the local population, even if they are required to be creative in finding ways to conduct business as normal.

Some authors have noted a decrease in certain types of TA within MCC, leading to a change in the way that the street is used and a loss of inclusivity. The official laws and regulations appear not to be the cause of this, but there is some conflict between how the authorities address the management of public space and how people have previously used these areas. In any case, what is unclear is whether the changes made to the built environment within MCC are improvements that have helped to maintain TA, preserving the social heritage of the site, or whether it has created a new life on the streets, one that benefits a small sector of society, or which even only exists for the benefit of tourists and other outsiders. Time plays an essential role in the changing use of public spaces and 
their TA, and this is an area where further research is required

A limitation of our research is that it only focusses on the laws and regulations for the use of the streets (and public spaces) in a particular area in the centre of Mexico City. It does not address fully how the streets are actually used and managed as public spaces within the city as a whole. Further research into the city's planning strategies, policies on urban street use, and the actual use of the street in other districts is needed to confirm our findings that the use of space is affected both by state law and local conventions, changes to which could have an impact on citizens' social obligations (Lara-Hernandez, Melis \& Lehmann, 2019).

Future studies on the topic in other cities and multicultural environments are also recommended. Cities are in a constant process of transformation, and the way in which they are designed and re-designed might affect the rational use of public spaces and their TA. A total of $68 \%$ of the world population will be living in urban areas by 2050 (United Nations, 2018), with urban areas seeing a corresponding increase in cultural diversity alongside population growth. Van Hook (2017) estimates that in the USA the diversity has increased by $98 \%$ in urban areas since 1980 . These socio-urban changes represent a challenge for urban design and planning. For instance, Pemberton (2016) points out that there is a lack of work about the role of urban planning towards diversity and migration. We have seen that TA has cultural components which may be specific to a specific place or ethnic group. Research is needed to investigate how cities that are more culturally diverse and/or which are facing high levels of national and international migration (such as London, Barcelona or Sydney) address the issue of the use of public space. It would be interesting to see how the forms of TA practiced in each city vary according to the presence of different cultural and religious groups living in the same area, and how this either coexists or comes into conflict with local legislation governing the use of the street.

\section{References}

Van der Aa, B.J.M. (2005). Preserving the heritage of humanity? Obtaining world heritage status and the impacts of listing. Rijksuniversiteit Groningen.

Alessandri Carlos, A.F. (20/4). La ciudad como privación y la reapropiación de lo urbano como ejercicio de la ciudadanía. Scripta Nova. Revista electrónica de geografia y ciencias sociales. [Online]. XVIII (493) pp.I-I3.

Anderson, S. (1986). On Streets. Cambridge, Massachusetts, MIT Press.

Arredondo, Í. (20I8). 9 marchasal día por 3 años. El Universal. [Online] 7 February, I-5. Available from: http://www.eluniversal.com.mx/periodismo-de-investigacion/cdmx-9-marchasal-dia-por3-anos.

Asamblea Legislativa del Distrito Federal III Legislatura (2004). Ley de Cultura Cívica del Distrito Federal. Gobierno Del Distrito Federal. [Online]. pp. I-29. Available from: http://www.aldf.gob.mx/archivo-0f05874fac7a0a4b94b9935dd0998eae.pdf.

Autoridad del Centro Historico (20II). Plan Integral de Manejo del Centro Historico de la Ciudad de Mexico (20II-20I6). Mexico, DF.

Bayón, M.C. (2008). Desigualdad y procesos de exclusión social. Concentración socioespacial de desventajas en el Gran Buenos Aires y la Ciudad de México. Estudios Demográficos y Urbanos. [Online] 23, I (67), I23-I50. DOI: 10.2307/403।5269. 
Bowen, G.A. (2009). Document Analysis as a Qualitative Research Method. Qualitative Research Journal. [Online] 9 (2): 27-40. DOI: I0.33 I6/QRJ0902027.

Campos Cortés, G.I. \& Brenna Becerril, J.E. (20I5). Repensando el espacio público como un bien común urbano. Argumentos. [Online] 28 (77), I57-176. Available from: http://www.redalyc.org/articulo.oa?id=59540679008.

Carrión, F. (2013). Dime quién financia el centro histórico y te diré qué centro histórico es. Revista Digital del Programa en Gestion de la Ciudad. (16) pp. I-26.

Castrejon-Arcos, D.E. (20I2). Sexo servidoras de la Merced. Ofrenda de día de muertos | DECA-Logos. [Online]. 2012. DECA-Logos. Available from: http://deca-logos.blogspot.com/2012/10/ofrendade-dia-de-muertos-de-las-sexo.html

Choay, F. (200I). The invention of the historic monument. [Online]. Cambridge University Press. DOI: $10.2307 / 991857$.

Cranz, G. (1982). The Politics of Park Design: A History of Urban Parks in America. MIT Press.

Crossa, V. (2009). Resisting the Entrepreneurial City: Street Vendors' Struggle in Mexico City's Historic Center. International Journal of Urban and Regional Research. [Online] 33 (I), 43-63. DOI: I 0. I I I I/j. I 468-2427.2008.00823.x.

Crouch, D. (1998). The street in the making of popular geographical knowledge. Images of the street: Planning, identity and control in public space. 160-175.

Deleuze, G. \& Guattari, F. (1989). A Thousand Plateaus: Capitalism and Schizophrenia. Brian Massumi (ed.). [Online]. Minneapolis, USA, University of Minnesota Press. DOI: 10.2307/203963.

Delgadillo, V. (20I4). La Política del espacio público y del patrimonio urbano en la Ciudad de México. Discurso progresista, negocios inmobiliarios y buen comportamiento social. In: XIII Coloquio Internacional de Geocrítica. 2014 Barcelona, España, Universitat de Barcelona.

Díaz Parra, R.I. (20I4). La transformación del centro histórico de la Ciudad de México. ¿Gentrificación o repoblación? In: XII Coloquio y Trabajos de Campo del Grupo de Geografia Urbana (AGE). Territorios inconclusos y sociedades rotas. 2014 Madrid y Castilla la Mancha. PP. I10.

Flores Arias, V. (20I5). El Centro Histórico de la Ciudad de México y sus retos en el siglo XXI. [Online]. 20I5. Planur-e. Available from: http://www.planur-e.es/articulos/ver/el-centro-histrico-de-la-ciudad-de-m-xico-y-sus-retos-en-el-siglo-xxi/completo [Accessed: I May 20I6].

Fonseca Rodriguez, J.M. (2015). La importancia y la apropiación de los espacios públicos en las ciudades. Revista de Tecnologia y Sociedad. 4 (7), I-II.

García Espinosa, S. (2005). Centros históricos ¿herencia del pasado o construcción del presente? Agentes detonadores de un nuevo esquema de ciudad. Scripta Nova. Revista electrónica de geografia y ciencias sociales. IX (39), I-I I.

Gehl, J. (20II). Life Between Buildings. Washington DC, Island Press.

Gehl, J. (20I4). Places for people. Melbourne, Australia, City of Melbourne. 
Gobierno de la Ciudad de México (20/4). Manual ciudadano para el cuidado del centro histórico. Fideicomiso Centro Histórico de la Ciudad de México. [Online]. p.95. Available from: http://www.autoridadcentrohistorico.cdmx.gob.mx/storage/app/uploads/public/58a/490/da3/58a 490da3b8ca502567977.pdf.

Gobierno del Distrito Federal (2016). Ley de Movilidad del Distrito Federal. [Online]. Pp.I-I0I. Available from: http://www.paot.org.mx/centro/leyes/df/pdf/20I6/LEY_MOVILIDAD_DISTRITO_FEDERAL_07 _10_2016.pdf.

Gobierno del Distrito Federal (20I3). Ley para el uso de las vías y los espacios públicos del Distrito Federal. Diario Oficial de la Federación. [Online]. DOI: 10.1017/CBO978I107415324.004.

Gobierno del Distrito Federal (20I5). Reglamento de Transito del Distrito Federal. [Online]. p. 124.

Gutierrez de Velasco Romo, E.G. \& Padilla Lozano, F. (20I2). Apropiación y uso del espacio público en el centro de la ciudad de Aguascalientes. Investigación y Ciencia. 20 (56), 33-43.

Habermas, J. (199I). The Structural Transformation of the Public Sphere: An Inquiry into a Category of Bourgeois Society. [Online]. Mass, Mit Press. DOI: 10.2307/2072652.

Hernández Bonilla, M. \& Gómez Gómez, S. (20I5). Conflicto espacial, exclusión y espacio público en la centralidad urbana de Xalapa, Veracruz. Revista Brasileira de Gestão Urbana. [Online] 7 (3), 28I-294. DOI: 10.1590/2I75-3369.007.003.AO04.

Herzog, L.A. (2004). Globalization and the Crisis of Public Space: The Example of Mexico. In: Gareth A. Jones \& Peter M. Ward (eds.). The End of Public Space in the Latin American City?. [Online]. 2004 Austin Texas, Mexican Center of LLILAS. pp. 5-8. Available from: http://lanic.utexas.edu/project/etext/lilas/cpa/mexcenter/endofpubspace.pdf .

Hidalgo, D. \& Graftieaux, P. (2008). Bus rapid transit systems in Latin America and Asia: Results and difficulties in II Cities. Transportation Research Record: Journal of the Transportation Research Board. [Online] 2072 (2072), 77-88. DOI: 10.3 I4I/2072-09.

Hiernaux-Nicolas, D. (2005). Transformaciones morfológicas de la Ciudad de México. Revista Veredas.pp.9-22.

Hook, J. Van (2017). Diversity is on the rise in urban and rural communities, and it's here to stay. [Online]. 2017. The Conversation. Available from: https://theconversation.com/diversity-is-onthe-rise-in-urban-and-rural-communities-and-its-here-to-stay-69095

INEGI (2018). Clima. Distrito Federal. [Online]. 20I8. Cuentame... Available from: http://cuentame.inegi.org.mx/monografias/informacion/df/territorio/clima.aspx?tema $=m e \& e=09$ [Accessed: 30 July 2018].

Jacobs, A.B. (1993). Great Streets: Monument Avenue, Richmond, Virginia. pp.22-28.

Jacobs, J. (196I). The Death and Life of Great American Cities. [Online]. DOI: 10.2307/794509. 
Janoschka, M. \& Sequera, J. (2014). Procesos de gentrificación y desplazamiento en América Latina - una perspectiva comparativista. Desafios metropolitanos. Un diálogo entre Europa y América Latina. (20|4), 82-104.

Keller, A.H. (2006). A road by any other name: trails, paths, and roads in Maya language and thought. In: Landscapes of Movement Symposium. 2006, p. 29.

Kim, A.M. (2013). Sidewalk City. [Online]. Chicago, US, The University of Chicago Press. DOI: I0.7208/chicago/9780226II9366.00I.000I.

Korosec-Serfaty, P. (1976). Appropriation of space. In: Proceedings of the Strasbourg conference. IAPC-3. 1976 Strasbourg-Lovaine La Neuve: CIACO.

Lara-Hernandez, J.A. \& Melis, A. (2018). Understanding the temporary appropriation in relationship to social sustainability. Sustainable Cities and Societies. [Online] 39C, I-I4. DOI: 10.1016/j.scs.2018.03.004.

Lara-Hernandez, J.A., Melis, A. \& Caputo, S. (2017). Understanding Spatial Configuration and Temporary Appropriation of the Street in Latin American cities: the case of Mexico City Centre Valeria Scavone, Maurizio Carta, Ferdinando Trapani, Fabio Naselli, et al. (eds.). Advances in Science, Technology \& Innovation. 153-173.

Lara-Hernandez, J.A., Melis, A. \& Lehmann, S. (2019). Temporary appropriation of public space as an emergence assemblage for the future urban landscape: The case of Mexico City. Future Cities and Environment. [Online] X, I-22. DOI: https://doi.org/I0.5334/fce.53.

Lefebvre, H. (I97I). De lo rural a lo urbano. Javier Gonzalez-Pueyo (ed.). Barcelona, España, Ediciones Peninsula.

Leon Portilla, M. (1995). Antologia de Tehotihuacan a los Aztecas. Fuentes e interpretaciones históricas. First re-i. Mexico, DF, Universidad Nacional Autonoma de Mexico.

Martinez-Ramirez, U. (20I5). Proceso de Gentrificación y Dezplazamiento en el espacio público del Centro Histórico de la Ciudad de México. [Online].

McAuslan, P. (2006). Legal Pluralism as a Policy Option: Is it Desirable, Is it Doable? Land Rights for African Development From Knowledge to Action. [Online] 2005, 9-10.

Mehta, V. (20I3). The Street. A Quintessential Social Public Space. New York, US, Routledge.

Minnery, J. (20I2). Sidewalks: Conflict and Negotiation over Public Space. Urban Policy and Research. [Online] I I46, I-2. DOI: I0.1080/08 I I I 46.20 I2.729694.

Monnet, J. (1996). Espacio público, comercio y urbanidad en Francia , México y Estados Unidos. ALTERIDADES. 6 (I I), II-25.

Monnet, J. (1995). Usos e imágenes del centro histórico de la Ciudad de México. Centro de estudios mexicanos y centroamericanos (ed.).

Moudon, A.V. (199I). Public Streets for Public Use. New York, US, Columbia University Press.

Mumford, L. (1938). The Culture of Cities. In: The Culture of Cities. London, UK, Anthony Rowe. Pp. $405-481$. 
Nelson, H.J. (1963). Townscapes of Mexico: An example of the regional variation of townscapes. Economic Geography. [Online] 39 (I), 74-83. Available from: http://www.jstor.org/stable/I 42496.

Nivon Bolan, E. \& Sanchez Bonilla, D. (2014). La gestión del Centro Histórico de la Ciudad de Mexico: 1980-2012. In: Lucía Durán, Eduardo Kingman Garcés, \& Mónica Lacarrieu (eds.). Habitar el Patrimonio Nuevos aportes al debate desde America Latina. Quito, Ecuador. Pp. 48-65.

Oehmichen, C. (2010). Espacio urbano y segregación étnica en la ciudad de México. Cuadernos de estudios sociales urbanos. [Online] (6), 6I-75. Available from: http://www.cedib.org/wpcontent/uploads/2013/05/villalibre_6.pdf\#page=62.

Pemberton, S. (2016). The challenge of superdiversity for urban planning. [Online]. 20I6. UPWEB. Available from: https://www.birmingham.ac.uk/generic/upweb/blog/2016/the-challenge-ofsuperdiversity-for-urban-planning.aspx

Portal, M.A. (2009a). Las creencias en el asfalto . La sacralización como una forma de apropiación del espacio público en la ciudad de México. Cuadernos de Antropología Social. (30), 59-75.

Portal, M.A. (2009b). Memoria y territorio: la sacralización simbólica del espacio urbano. In: La Historia Oral y la multidisciplinariedad: retos y perspectivas. 2009 Colima, Mexico, Departamento de Antropología UAM-I. PP. I-9.

Purcell, M. (2002). Excavating Lefebvre: The right to the city and its urban politics of the inhabitant. GeoJournal. [Online] 58, 99-108. DOI: I0.1023/B:GEJO.00000I0829.62237.8f.

Ramirez-Lovering, D. (2008) Opportunistic urbanism. Melbourne, Australia, RMIT Press.

Ramirez Kuri, P. (20I5). Espacio público, ¿espacio de todos? Reflexiones desde la ciudad de México. Revista mexicana de sociologia. I (77), 7-36.

Ramirez Kuri, P. (2008). La fragilidad del espacio publico en la ciudad segregada. In: Rolanco Cordera, Patricia Ramirez Kuri, \& Alicia Ziccardi (eds.). Pobreza, desigualdad y exclusión social en la ciudad del siglo XXI. Mexico, DF, Siglo XXI editores. PP. I-25.

Ramírez Kuri, P. (2010). La ciudad y los nuevos procesos urbanos. Sociología Urbana. 163-187.

Patricia Ramirez Kuri (ed.) (2016). La reinvencion del espacio publico en la ciudad fragmentada. Mexico City, Universidad Nacional Autonoma de Mexico.

Redacción ADN (2015). Inversión por 16 MDP en parques públicos y espacios deportivos en Oaxaca: Administración (20:40 h) < ADN - Agencia Digital de Noticias Sureste. [Online]. 20I5. ADN Sureste. Available from: http://adnsureste.info/inversion-por-16-mdp-en-parques-publicos-yespacios-deportivos-en-oaxaca-administracion-2040-h/

Rivera, D. (1945). La Gran Tenochtitlan. [Online]. 1945. Commons Wikimedia. Available from: https://commons.wikimedia.org/wiki/File:La_Gran_Tenochtitlan.JPG [Accessed: 29 August 2017]. 
Roy, A. \& Alsayyad, N. (2004). Urban informality: Transnational perspectives from Midle East, Latin America and South Asia. Oxford, UK, Lexington Books.

Sansot, P. (1976). Notes sur le concept d'appropriation. In: Conférence Internationale de Psychologie de l'Espace Construit (3rd IAPS) de Strasbourg. 1976 Strasbourg, France. pp. 67-75.

Santino, J. (1992). Yellow Ribbons and Seasonal Fla The Folk Assemblage of War. The Journal of American Folklore. 105 (4I5), 19-33.

Saraví, G.A. (2008). Mundos Aislados: Segregación Urbana y Desigualdad en la Ciudad de México. EURE (Santiago). [Online] 34 (I03), 93-I I0. DOI: 10.4067/S0250-7I 6I 2008000300005.

Stanislawski, D. (1947). Early Spanish Town Planning in the New World. American Geographical Society. 37 (I), 94-105.

Suárez Pareyón, A. (2004). El centro histórico de la Ciudad de México al inicio del siglo XXI. Revista invi.19 (5I) Pp.75-95.

Torres, E. (2009). Apropiación Versus Usos Del Espacio Público. [Online] Available from: https://www.mardelplata.gob.ar/documentos/policia/taller I cultura y territorio apuntes.pdf [Accessed: I November 2017].

United Nations (20I8). 68\% of the world population projected to live in urban areas by 2050, says UN I UN DESA | United Nations Department of Economic and Social Affairs. [Online]. 20I8. Available from: https://www.un.org/development/desa/en/news/population/20/8-revision-of-worldurbanization-prospects.html [Accessed: 17 September 2018].

Villanueva, N., Vazquez, R., Hernandez, S., Chiu, J., et al. (2012). Metodología para la Construcción del Sistema de Indicadores de Prevención Social de la Violencia y la Delincuencia Septiembre de 2012.

Webster, D. \& Sanders, W. (200I). La antigua ciudad mesoamericana: teoría y concepto. Urbanismo En Las Sociedades Antiguas. [Online] 43-64. Available from: http://dialnet.unirioja.es/servlet/articulo?codigo $=2776058$.

Whyte, W.H. (1980). The Social Life of Small Urban Spaces. [Online]. DOI: 10.1177/0891241682010004II.

Yory García, C.M. (2003). Topofilia, ciudad, territorio: una estrategia pedagógica de desarrollo urbano participtivo con dimensión sustentable para las grandes metrópolis de América Latina en el contexto de la globalización: 'el caso de la ciudad de Bogotá'. [Online]. Universidad Complutense de Madrid. Available from: http://biblioteca.ucm.es/tesis/ghi/ucm-t26725.pdf.

Yory, M.C. (20I I). El Concepto de Topofilia entendido como Teoría del Lugar. Revista Barrio Taller. I-I7. 